\title{
The Genetic Basis of Delayed Puberty
}

\author{
Sasha R. Howard Leo Dunkel \\ Centre for Endocrinology, William Harvey Research Institute, Barts and The London School of Medicine and \\ Dentistry, Queen Mary University of London, London, UK
}

\section{Keywords}

Pubertal timing · Self-limited delayed puberty .

Constitutional delay - Genetics - Adolescent development

\begin{abstract}
The genetic control of puberty remains an important but mostly unanswered question. Late pubertal timing affects over $2 \%$ of adolescents and is associated with adverse health outcomes including short stature, reduced bone mineral density, and compromised psychosocial health. Self-limited delayed puberty (DP) is a highly heritable trait, which often segregates in an autosomal dominant pattern; however, its neuroendocrine pathophysiology and genetic regulation remain unclear. Some insights into the genetic mutations that lead to familial DP have come from sequencing genes known to cause gonadotropin-releasing hormone (GnRH) deficiency, most recently via next-generation sequencing, and others from large-scale genome-wide association studies in the general population. Investigation of the genetic control of DP is complicated by the fact that this trait is not rare and that the phenotype is likely to represent a final common pathway, with a variety of different pathogenic mechanisms affecting the release of the puberty "brake." These include abnormalities of GnRH neuronal development and function, GnRH receptor and luteinizing hormone/follicle-
\end{abstract}

stimulating hormone abnormalities, metabolic and energy homeostatic derangements, and transcriptional regulation of the hypothalamic-pituitary-gonadal axis. Thus, genetic control of pubertal timing can range from early fetal life via development of the GnRH network to those factors directly influencing the puberty brake during mid-childhood.

(c) 2017 S. Karger AG, Basel

\section{Introduction}

Puberty is the maturational process of the reproductive endocrine system that results in achievement of adult height and body proportion, in addition to development of the genital organs and the capacity to reproduce. The onset of puberty is driven by an increase in the pulsatile release of gonadotropin-releasing hormone $(\mathrm{GnRH})$ from the hypothalamus. This activation results in increased luteinizing hormone ( $\mathrm{LH}$ ) and follicle-stimulating hormone (FSH) release from the anterior pituitary; both hormones act on the gonads to stimulate their development, gametogenesis, and sex steroid production.

The development of the hypothalamic-pituitary-gonadal (HPG) axis is exceptional in that GnRH neurons develop in metazoan embryos outside of the central ner-

\section{KARGER}

(c) 2017 S. Karger AG, Basel

E-Mail karger@karger.com

www.karger.com/nen
Leo Dunkel

Centre for Endocrinology, William Harvey Research Institute

Barts and The London School of Medicine and Dentistry

Queen Mary University of London, London EC1M 6BQ (UK)

E-Mail l.dunkel@ qmul.ac.uk 
Fig. 1. The genetics of pubertal timing. In the general population there is a near-normal distribution of the timing of pubertal onset, with the definitions of precocious and delayed being statistically determined (+/-2 standard deviations [SD]). Strategies to determine key genetic determinants in the timing of puberty include large genome-wide association studies (GWAS) of age at menarche and voice breaking in the general population, and identification of rare high-impact variants causing early, late, or absent puberty in patients and their families. G2, Tanner genital stage 2 in boys; yr, years.

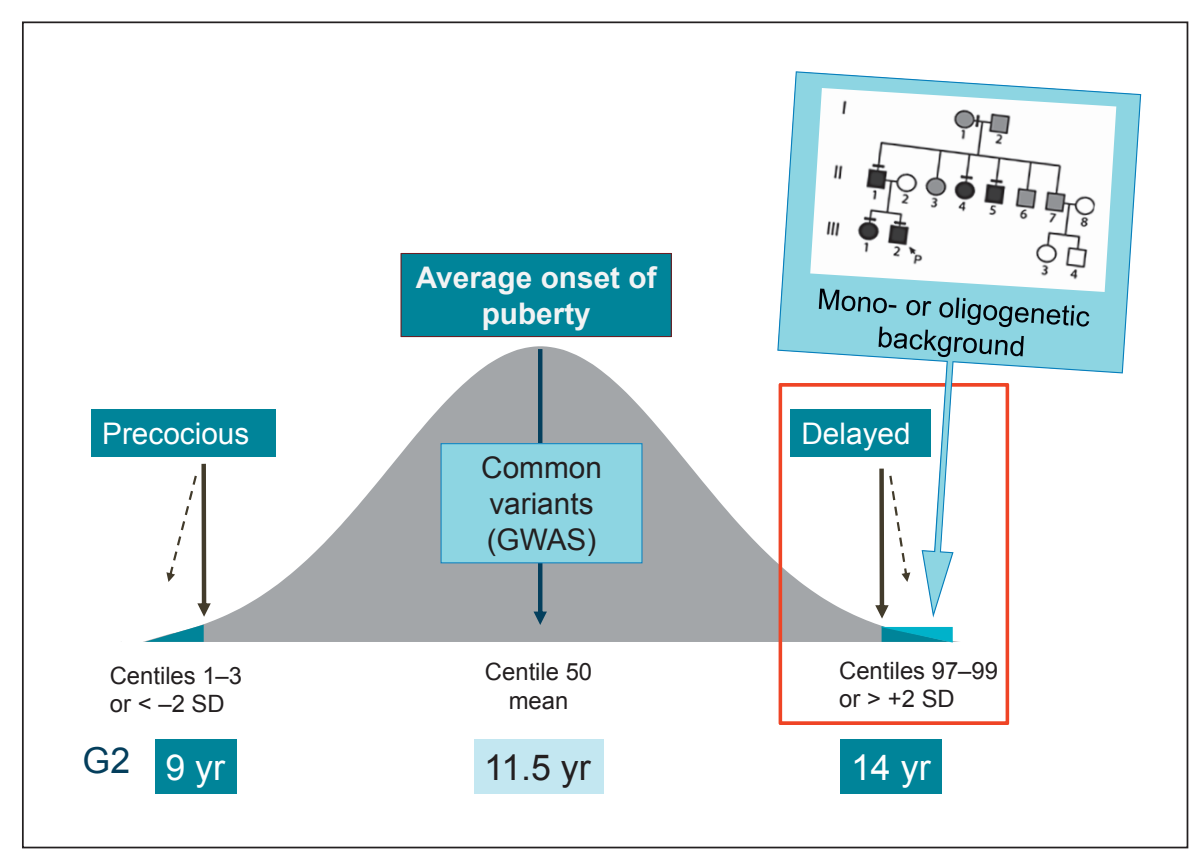

vous system. Immature GnRH precursor neurons are first detectable in the olfactory placode in the nose from an early embryological stage, and then begin a complex journey towards the hypothalamus [1].

The axis is active in fetal and in early infant life, the socalled "mini-puberty," and then becomes dormant between the age of 1 and 8-9 years [2]. Development of the clinical features of puberty is initiated by the reactivation of the HPG axis after this relative quiescence during childhood. What drives this suppression of the axis during childhood, and what controls the release of this "brake" and the timing at which this occurs, is little understood.

Despite the demonstrated importance of environmental factors such as body mass, psychosocial stressors, and endocrine disrupting chemicals [3], the genetic influence on the timing of puberty is clearly fundamental. Whilst the timing of pubertal onset varies within and between different populations, it is a highly heritable trait. The timing of sexual maturation is highly correlated within families and in twin studies, suggesting strong genetic determinants [4]. Previous epidemiological studies and genetic approaches estimate that $60-80 \%$ of the variation in pubertal onset is under genetic regulation $[5,6]$. However, despite this strong heritability, little is known about the genetic control of human puberty, either in the normal population or in cases of disturbed pubertal timing [7].

\section{Investigating the Inheritance of Delayed Puberty}

Self-limited delayed puberty (DP), also known as constitutional delay of growth and puberty, represents the extreme end of normal pubertal timing, and is defined as the absence of testicular enlargement in boys or breast development in girls at an age that is 2 to 2.5 standard deviations later than the population mean [7]. In addition, cases of self-limited DP may also encompass older children with delayed pubertal progression, a diagnosis that is aided by the use of puberty nomograms [8]. Self-limited DP is associated with adverse health outcomes including short stature, reduced bone mineral density, and compromised psychosocial health [9].

Self-limited DP represents the commonest cause of DP in both sexes. Up to $63 \%$ of boys with pubertal delay have self-limited DP [10]. Self-limited DP segregates within families with complex patterns of inheritance including autosomal dominant, autosomal recessive, bilineal, and $\mathrm{X}$-linked [11], although sporadic cases are also observed (Fig. 1). The majority of families display an autosomal dominant pattern of inheritance (with or without complete penetrance) $[4,11]$. Fifty to $75 \%$ of subjects with self-limited DP have a family history of delayed pubertal onset [11].

Analysis of self-limited DP families is complicated by the fact that this phenotype represents the tail of a normally distributed trait within the population, so it is ex- 
pected that variants that govern the inheritance of this condition will also be present in the general population at a low level. Thus, the absence of these variants in population databases cannot be used as an exclusion criterion. Instead, a comparison of prevalence rates of such variants must be made to identify those that are enriched in patients compared to the general population. In the majority of patients with DP the neuroendocrine pathophysiology and its genetic regulation remain unclear. Linkage analysis and targeted sequencing strategies appear to have been superseded by whole exome and genome sequencing strategies to identify novel candidate genes.

\section{Evidence from Population Studies}

Attempts to identify key genetic regulators of the timing of puberty in humans have led to several large genome-wide association studies of age at menarche, examining pubertal timing in healthy women [12-14]. These studies demonstrate genetic heterogeneity in pubertal timing, with the observation that the genetic architecture of the timing of puberty in healthy subjects is likely to involve at least hundreds of common variants. The first of many loci associated with age at menarche was the gene LIN28B [15]. LIN28B is a human orthologue of the gene that controls, through microRNAs, developmental timing in Caenorhabditis elegans. However, mutations in LIN28B have not to date been identified in human patients with DP [16] or precocious puberty [17].

The most recent study of this type comprises 1000 Genomes Project-imputed genotype data from up to $\sim 370,000$ women, and identifies 389 independent signals $\left(p<5 \times 10^{-8}\right)$ for age at menarche [18]. The per-allele effect sizes ranged from 1 week to 5 months. These signals explain $\sim 7.4 \%$ of the population variance in age at menarche, corresponding to $\sim 25 \%$ of the estimated heritability. Many of these signals have concordant effects on the age at voice breaking, a corresponding milestone in males. However, in women the signals identified had stronger effects on early than on late age at menarche, but in contrast had larger effect estimates for relatively late than relatively early voice breaking in males [18].

Around 250 genes were identified via coding variation or associated expression, particularly those expressed in neural tissues. Importantly, genes already implicated in rare disorders of puberty were identified, including $L E P R$, GNRH1, KISS1, and TACR3. Two imprinted genes were also reported: $M K R N 3$, paternally inherited mutations in which have been identified as causal in pedigrees of central precocious puberty (CPP) [19], and DLK1 [20]. $M K R N 3$ is the third, and to date the most frequently mutated, gene in pedigrees with CPP [19], the others being KISS1 [21] and its receptor GPR54 [22], which have been reported only rarely. MKRN3 is thought to contribute to the puberty "brake" restraining the HPG axis via inhibition of GnRH release. Very recently a complex defect in $D L K 1$ has been identified in one pedigree with CPP [20]. However, neither MKRN3 nor DLK1 mutations have been implicated in the pathogenesis of DP (Fig. 2).

\section{Genetics of GnRH Deficiency or Signalling}

At the extreme end of the spectrum of DP are conditions of $\mathrm{GnRH}$ deficiency including hypogonadotropic hypogonadism $(\mathrm{HH})$, with complete failure to enter puberty. The condition may be due to failure of development of GnRH neurons, lack of activation of GnRH secretion, or disrupted GnRH signalling. Because of different causes and incomplete penetrance, there is a wide spectrum of phenotypes, ranging from complete $\mathrm{HH}$ with lack of pubertal development to a partial hypogonadism with an arrest of pubertal development, and even reversible $\mathrm{HH}$ in some patients after treatment $[23,24]$. Despite recent advances, with over 20 genes linked to this disorder identified, the pathophysiological basis of $\mathrm{HH}$ in approximately $50 \%$ of individuals remains unclear [2]. In view of the possible overlap between the pathophysiology of DP and conditions of GnRH deficiency, a few studies have examined the contribution of mutations in $\mathrm{HH}$ genes to the phenotype of self-limited DP.

Loss-of-function mutations within the $\mathrm{GnRH}$ receptor are the most frequent cause of autosomal recessive idiopathic $\mathrm{HH}$, accounting for $16-40 \%$ of patients. Mutations have been found within the extracellular, transmembrane, and intracellular domains of the receptor, leading to impaired GnRH action [25]. A homozygous partial loss-of-function mutation in GNRHR was found in 2 brothers, 1 with self-limited DP and 1 with idiopathic $\mathrm{HH}$ [26], and a further heterozygous mutation was found in 1 male with self-limited DP [27]. A small cohort of 31 patients was analysed for mutations in GHSR, and 5 patients were found to have point mutations in this gene [28]. Additionally, mutations in HS6ST1, FGFR1, and newly in $K L B$ have been found in a small number of kindreds of $\mathrm{HH}$ patients and their relatives with DP [29-31]. Recently, variants in several HH genes including GNRHR, TAC3, TACR3, IL17RD, and SEMA3A have been identified by whole exome sequencing in some cases of DP, including 
Fig. 2. Overlap between genetic regulation in the general population and extreme phenotypes. Examples of genes implicated in the timing of puberty from genome-wide association studies (GWAS) in the general population, conditions of gonadotropinreleasing hormone $(\mathrm{GnRH})$ deficiency such as idiopathic hypogonadotropic hypogonadism (IHH) and Kallmann syndrome (KS), and self-limited delayed puberty.

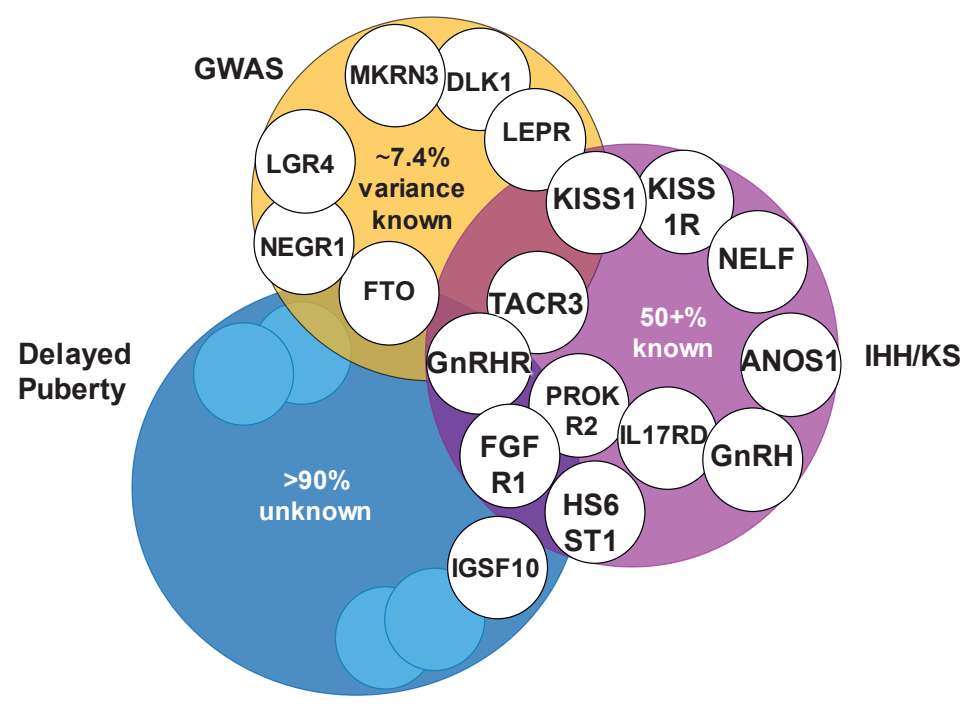

self-limited DP [32]. However, these variants have not been tested in vitro or in vivo for pathogenicity and thus may be an overestimation. However, the current picture indicates that the genetic background of $\mathrm{HH}$ and DP may be largely different, or shared by as yet undiscovered genes [27].

Genetic defects affecting the development of the anterior pituitary may also cause GnRH deficiency. The pituitary transcription factors $L H X 3, S O X 2$, and HESX1 are vital for early patterning of the forebrain and pituitary, and mutations in these developmental genes result in syndromic hypopituitarism with gonadotropin deficiency in humans [33]. PROP1 is important for the development of gonadotropin-secreting cells, and mutations in this gene are the most common cause of combined pituitary hormone deficiency in humans [34]. Patients with PROP1 mutations have variable GnRH deficiency ranging from DP to congenital $\mathrm{HH}$ [33]. Mutations in DAX1 cause $\mathrm{X}$-linked adrenal hypoplasia congenita with associated $\mathrm{HH}$, but have not been found in cases of isolated DP [35].

GnRH deficiency may also be associated with other conditions, particularly with neurological phenotypes. Mutations in $P O L R 3 A / B$ result in the $4 \mathrm{H}$ syndrome (hypomyelination, hypodontia, and hypogonadotropic hypogonadism) [36], whilst those in RNF216, OTUD4, and PNPLA6 produce the phenotypic combination of $\mathrm{HH}$ and ataxia (also known as Gordon Holmes syndrome) $[37,38]$. DMXL2 mutations are associated with congenital $\mathrm{HH}$, other endocrine deficiencies, and polyneuropathies [39]. Dysregulation of the RAB3 cycle, such as with mutations in RAB3GAP1, leads to Warburg Micro syndrome with ocular, neurodevelopmental, and central reproductive defects [40,41].

Downstream mutations in the GnRH signalling pathway can also present as DP. LH and FSH are glycoprotein hormones encoded by a common $\alpha$-subunit gene and a specific $\beta$-subunit gene. Mutations of the $\beta$-subunit genes of LH or FSH are extremely rare causes of pubertal abnormalities [42]. Males with inactivating mutations of the $L H B$ have absent pubertal development with Leydig cell hypoplasia leading to $\mathrm{T}$ deficiency and azoospermia. Females with inactivating mutations of $L H B$ present with onset of normal puberty, but with normal or late menarche followed by infertility due to lack of ovulation [42]. Individuals with inactivating FSHB mutations present with incomplete pubertal development and azoospermia if they are male, and with primary amenorrhoea if they are female [43].

\section{Upstream Regulation of the HPG Axis}

Kisspeptin, an excitatory neuropeptide, was identified as a permissive factor in puberty onset by the discovery of patients with $\mathrm{GnRH}$ deficiency with loss-of-function mutations in the KISS1 receptor, KISS1R (previously known as GPR54) [44, 45]. Mice with knockout of Kiss1r were 
simultaneously discovered to be infertile despite anatomically normal GnRH neurons and normal hypothalamic GnRH levels [45], with a phenotype consistent with normosmic GnRH deficiency. However, to date, only very rarely have human mutations in KISS1 been found in patients with delayed or absent puberty [46].

The excitatory neuropeptide neurokinin $\mathrm{B}$ also plays a role in the upstream control of $\mathrm{GnRH}$ secretion. Identification of this pathway occurred also via discovery of lossof-function mutations in TAC3, encoding neurokinin $\mathrm{B}$, and its receptor TACR3 in patients with normosmic $\mathrm{GnRH}$ deficiency and pubertal failure [47]. Kisspeptin, neurokinin B, and dynorphin are coexpressed in KNDy neurons of the arcuate nucleus of the hypothalamus [48], which project to and directly interact with GnRH neurons. Their expression is downregulated by oestrogen and testosterone as part of the negative feedback regulation of gonadotropin secretion $[49,50]$. However, administration of neurokinin $\mathrm{B}$ agonists failed to stimulate GnRH release in rodents, and Tacr3 knockout mice have grossly normal fertility $[51,52]$. Among 50 self-limited DP patients investigated for mutations in TAC3 and TACR3, only 1 mutation in a single patient was found in the latter gene [53].

The inhibitory role of GABAergic neurotransmission has been clearly shown in primates [54] but is more ambiguous in rodents. Opioid peptides provide additional inhibitory input, but this appears to be less critical than the GABAergic signals in restraining the initiation of puberty [55]. Additionally, RFamide-related peptide gene $(R F R P)$, the mammalian orthologue of the avian peptide gonadotropin-inhibiting hormone $(G n I H)$, has been identified as a further inhibitory regulator of $\mathrm{GnRH}$ neuronal activity in mice [56]. Glial inputs appear to be predominantly facilitatory during puberty and consist of growth factors and small diffusible molecules, including TGF- $\beta_{1}$, IGF- 1 , and neuregulins, that directly or indirectly stimulate GnRH secretion [57].

Upstream regulation of $\mathrm{GnRH}$ transcription is less well established. Candidate transcriptional regulators identified from a systems biology approach and animal models include Oct-2, TTF-1, and EAP1 [58]. Oct-2 mRNA is upregulated in the hypothalamus in juvenile rodents, and blockage of Oct- 2 synthesis delays the age at first ovulation, whilst activation of Oct- 2 expression (e.g., hamartomas) induces precocious puberty [59]. TTF-1 (thyroid transcription factor 1) enhances GnRH expression, with increased expression in pubertal rhesus monkeys [60]. EAP1 mRNA levels also increase in the hypothalamus of primates and rodents during puberty. EAP1 transactivates the GnRH promoter, and EAP1 knockdown with siRNA caused DP and disrupted oestrous cyclicity in a rodent model [61]. However, to date no mutations in these upstream or regulatory factors have been reported in patients with DP.

Epigenetic regulators are potential mediators of the effects of the environment on the hypothalamic regulation of puberty. However, whilst experimental data from rats give evidence for changes in histone acetylation and gene methylation leading to altered gene expression during puberty, the link between environmental factors and epigenetic control of puberty via the hypothalamus has not been established. Recent evidence highlights the importance in mice of microRNAs (particularly the miR200/429 family and miR-155) in the epigenetic upregulation of $\mathrm{GnRH}$ transcription during the critical period (murine equivalent of the mini-puberty) [62]. Epigenetic changes during fetal life are also a potential mechanism for the effects of endocrine disrupting chemicals in utero [63].

\section{Metabolism and Timing of Puberty}

Nutritional changes play an important role in the observed secular trend towards an earlier age of pubertal onset in the developed world [64], as shown by the positive correlation between age at puberty onset and childhood body size, particularly in girls [65]. In contrast, undernutrition in females - for example, in chronic disease or anorexia nervosa - can result in delay in both the onset and the tempo of puberty [66].

This relationship between fat mass and pubertal timing is mediated, at least in part, through the permissive actions of the metabolic hormone leptin, a key regulator of body mass, produced from white adipose tissue [67]. Humans and mice lacking leptin (Lep ob/ob) or the leptin receptor (LepR $\mathrm{db} / \mathrm{db}$ ) fail to complete puberty and are infertile [68]. Genome-wide association studies of pubertal timing found, in addition to leptin signalling, overlap with several genes implicated in body mass index, including FTO, SEC16B, TMEM18, and NEGR1 [18]. However, whilst self-limited DP in boys is associated with hypoleptinaemia [69], there have been no identified associations of specific leptin or leptin receptor polymorphisms with DP [70]. Ghrelin and other gut-derived peptides may also form part of the mechanism by which energy homeostasis regulates reproductive development [71]. Notably, children with constitutional delay of growth and puberty have a dual phenotype of slow growth in child- 
Fig. 3. Schematic of the mechanism by which IGSF10 mutations lead to delayed puberty. Reduced levels of IGSF10 expression during embryogenesis in the corridor of the nasal mesenchyme from the vomeronasal organ (VNO) to the olfactory bulbs result in delayed migration of gonadotropin-releasing hormone ( $\mathrm{GnRH})$ neurons to the hypothalamus. This presents for the first time in adolescence as a phenotype of delayed puberty due to abnormalities of the GnRH neuronal network.

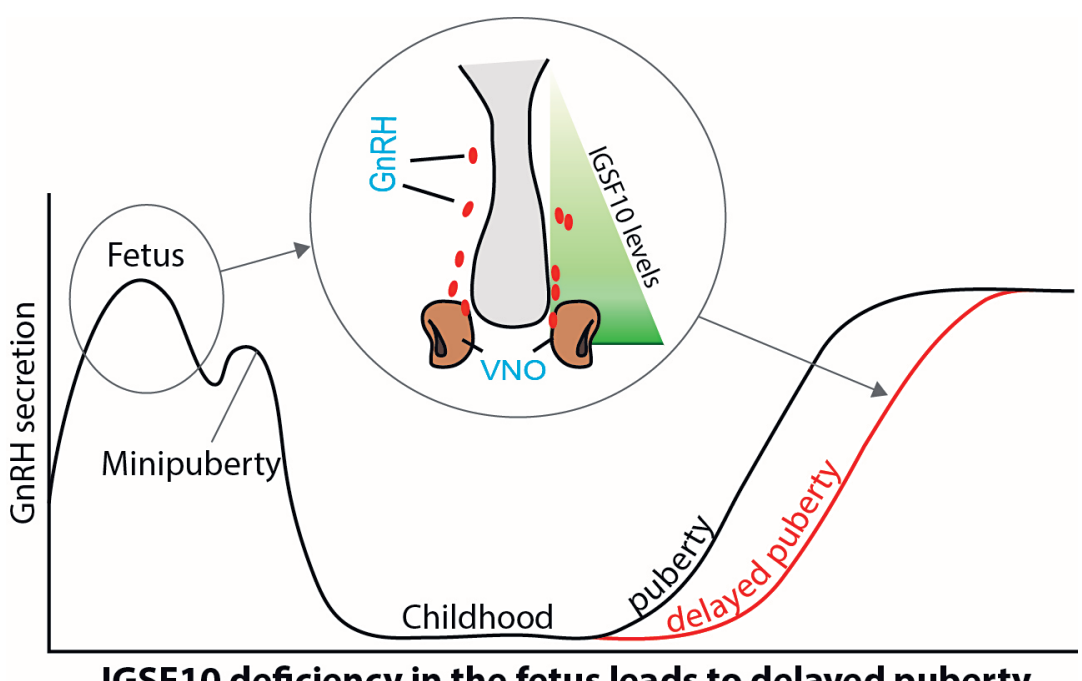

IGSF10 deficiency in the fetus leads to delayed puberty

hood with DP. In contrast, both low birth weight and prematurity are associated with earlier onset of puberty [72], particularly in those children with a rapid increase in length or weight in the first 2 years of life [73]. It remains unclear, however, whether childhood obesity, insulin resistance, excess androgens, or underlying genetic or epigenetic factors may explain this association [74].

\section{Recent Advances}

Loss-of-function mutations in a member of the immunoglobulin superfamily, IGSF1, have been identified in patients with X-linked central hypothyroidism [75]. Notably, male patients with IGSF1 mutations have a late increase in testosterone levels with a delayed pubertal growth spurt. However, pathogenic mutations in IGSF1 have not been conclusively found in patients with isolated DP [76].

More recently, whole exome and targeted resequencing methods have implicated 2 pathogenic mutations in IGSF 10 as the causal factor for late puberty in 6 unrelated families from a large Finnish cohort with familial DP [77]. A further 2 rare variants of unknown significance were identified in 4 additional families from the cohort. Mutations in IGSF10 appear to cause a dysregulation of $\mathrm{GnRH}$ neuronal migration during embryonic development (Fig. 3). An intact GnRH neurosecretory network is necessary for the correct temporal pacing of puberty.
Pathogenic IGSF10 mutations leading to disrupted IGSF10 signalling potentially result in reduced numbers or mistimed arrival of GnRH neurons at the hypothalamus, producing a functional defect in the GnRH neuroendocrine network. With this impaired GnRH system there would follow an increased "threshold" for the onset of puberty, with an ensuing delay in pubertal timing. IGSF10 loss-of-function mutations were also discovered in patients with a hypothalamic amenorrhoea-like phenotype. These findings represent a new fetal origin of self-limited DP, and reveal a potential shared pathophysiology between DP and other forms of functional hypogonadism.

\section{Conclusions}

This review serves to highlight the fascinating heterogeneity of genetic defects resulting in delayed and disordered puberty. Although our understanding of the highly complex underlying biological network remains imperfect, results to date have demonstrated the importance of defects in GnRH neuronal development and function GnRH receptor and LH/FSH abnormalities, transcriptional regulation of the HPG axis, and metabolic and energy homeostatic derangements - in the control of pubertal timing.

Clinically the distinction in adolescence between the conditions of DP and congenital idiopathic $\mathrm{HH}$ is an im- 
portant but difficult one. Both disorders can present with a picture of functional hypogonadotropism and in some cases may share an underlying pathophysiology. There remains no definitive test to accurately discriminate between the two diagnoses. More complex and involved management is required in patients with hypogonadism to achieve both development of secondary sexual characteristics and to maximize the potential for fertility [78]. A rapid and efficient diagnosis of patients in the clinic would represent a huge leap forward in patient care and a likely significant economic advantage. While presently next-generation sequencing in individuals presenting with delayed or incomplete pubertal development is only a reasonable option in a research setting, future progress in gene discovery and technical developments may facilitate the availability of genetic diagnosis as part of clinical care for patients with both GnRH deficiency and self-limiting DP.

\section{References}

1 Cariboni A, Maggi R, Parnavelas JG: From nose to fertility: the long migratory journey of gonadotropin-releasing hormone neurons. Trends Neurosci 2007;30:638-644.

2 Karges B, Neulen J, de Roux N, Karges W: Genetics of isolated hypogonadotropic hypogonadism: role of $\mathrm{GnRH}$ receptor and other genes. Int J Endocrinol 2012;2012:147893.

3 de Muinich Keizer SM, Mul D: Trends in pubertal development in Europe. Hum Reprod Update 2001;7:287-291.

4 Wehkalampi K, Widén E, Laine T, Palotie A, Dunkel L: Patterns of inheritance of constitutional delay of growth and puberty in families of adolescent girls and boys referred to specialist pediatric care. J Clin Endocrinol Metab 2008; $93: 723-728$.

5 Gajdos ZK, Hirschhorn JN, Palmert MR: What controls the timing of puberty? An update on progress from genetic investigation. Curr Opin Endocrinol Diabetes Obes 2009; 16:16-24.

6 Parent AS, Teilmann G, Juul A, Skakkebaek NE, Toppari J, Bourguignon JP: The timing of normal puberty and the age limits of sexual precocity: variations around the world, secular trends, and changes after migration. Endocr Rev 2003;24:668-693.

7 Palmert MR, Dunkel L: Clinical practice. Delayed puberty. N Engl J Med 2012;366:443453.

8 Lawaetz JG, Hagen CP, Mieritz MG, Blomberg Jensen M, Petersen JH, Juul A: Evaluation of 451 Danish boys with delayed puberty: diagnostic use of a new puberty nomogram and effects of oral testosterone therapy. J Clin Endocrinol Metab 2015;100:1376-1385.

9 Zhu J, Chan YM: Adult consequences of selflimited delayed puberty. Pediatrics 2017; 139:e20163177.

10 Sedlmeyer IL, Palmert MR: Delayed puberty: analysis of a large case series from an academic center. J Clin Endocrinol Metab 2002;87: 1613-1620.

11 Sedlmeyer IL, Hirschhorn JN, Palmert MR: Pedigree analysis of constitutional delay of growth and maturation: determination of familial aggregation and inheritance patterns. J Clin Endocrinol Metab 2002;87:5581-5586.
12 Ong KK, Elks CE, Li S, Zhao JH, Luan J, Andersen LB, et al: Genetic variation in LIN28B is associated with the timing of puberty. Nat Genet 2009;41:729-733.

13 Perry JR, Day F, Elks CE, Sulem P, Thompson DJ, Ferreira T, et al: Parent-of-origin-specific allelic associations among 106 genomic loci for age at menarche. Nature 2014;514:92-97.

14 Elks CE, Perry JR, Sulem P, Chasman DI, Franceschini N, He C, et al: Thirty new loci for age at menarche identified by a meta-analysis of genome-wide association studies. Nat Genet 2010;42:1077-1085.

15 Perry JR, Stolk L, Franceschini N, Lunetta KL, Zhai G, McArdle PF, et al: Meta-analysis of genome-wide association data identifies two loci influencing age at menarche. Nat Genet 2009;41:648-650.

16 Tommiska J, Wehkalampi K, Vaaralahti K, Laitinen EM, Raivio T, Dunkel L: LIN28B in constitutional delay of growth and puberty. J Clin Endocrinol Metab 2010;95:3063-3066.

17 Silveira-Neto AP, Leal LF, Emerman AB, Henderson KD, Piskounova E, Henderson $\mathrm{BE}$, et al: Absence of functional LIN28B mutations in a large cohort of patients with idiopathic central precocious puberty. Horm Res Paediatr 2012;78:144-150.

18 Day FR, Thompson DJ, Helgason H, Chasman DI, Finucane H, Sulem P, et al: Genomic analyses identify hundreds of variants associated with age at menarche and support a role for puberty timing in cancer risk. Nat Genet 2017;49:834-841.

19 Abreu AP, Dauber A, Macedo DB, Noel SD, Brito VN, Gill JC, et al: Central precocious puberty caused by mutations in the imprinted gene MKRN3. N Engl J Med 2013;368:24672475.

20 Dauber A, Cunha-Silva M, Macedo DB, Brito VN, Abreu AP, Roberts SA, et al: Paternally inherited DLK1 deletion associated with familial central precocious puberty. J Clin Endocrinol Metab 2017;102:1557-1567.

21 Silveira LG, Noel SD, Silveira-Neto AP, Abreu AP, Brito VN, Santos MG, et al: Mutations of the KISS1 gene in disorders of puberty. J Clin Endocrinol Metab 2010;95:2276-2280.
22 Teles MG, Bianco SD, Brito VN, Trarbach EB, Kuohung W, Xu S, et al: A GPR54-activating mutation in a patient with central precocious puberty. N Engl J Med 2008;358:709-715.

23 Raivio T, Falardeau J, Dwyer A, Quinton R, Hayes FJ, Hughes VA, et al: Reversal of idiopathic hypogonadotropic hypogonadism. N Engl J Med 2007;357:863-873.

24 Pitteloud N, Quinton R, Pearce S, Raivio T, Acierno J, Dwyer A, et al: Digenic mutations account for variable phenotypes in idiopathic hypogonadotropic hypogonadism. J Clin Invest 2007;117:457-463.

25 Chevrier L, Guimiot F, de Roux N: GnRH receptor mutations in isolated gonadotropic deficiency. Mol Cell Endocrinol 2011;346: 21-28.

26 Lin L, Conway GS, Hill NR, Dattani MT, Hindmarsh PC, Achermann JC: A homozygous R262Q mutation in the gonadotropinreleasing hormone receptor presenting as constitutional delay of growth and puberty with subsequent borderline oligospermia. J Clin Endocrinol Metab 2006;91:5117-5121.

27 Vaaralahti K, Wehkalampi K, Tommiska J, Laitinen EM, Dunkel L, Raivio T: The role of gene defects underlying isolated hypogonadotropic hypogonadism in patients with constitutional delay of growth and puberty. Fertil Steril 2011;95:2756-2758.

28 Pugliese-Pires PN, Fortin JP, Arthur T, Latronico AC, Mendonca BB, Villares SM, et al: Novel inactivating mutations in the GH secretagogue receptor gene in patients with constitutional delay of growth and puberty. Eur J Endocrinol 2011;165:233-241.

29 Tornberg J, Sykiotis GP, Keefe K, Plummer L, Hoang X, Hall JE, et al: Heparan sulfate 6-Osulfotransferase 1 , a gene involved in extracellular sugar modifications, is mutated in patients with idiopathic hypogonadotrophic hypogonadism. Proc Natl Acad Sci USA 2011; 108:11524-11529.

30 Pitteloud N, Meysing A, Quinton R, Acierno JS Jr, Dwyer AA, Plummer L, et al: Mutations in fibroblast growth factor receptor 1 cause Kallmann syndrome with a wide spectrum of reproductive phenotypes. Mol Cell Endocrinol 2006;254-255:60-69. 
31 Xu C, Messina A, Somm E, Miraoui H, Kinnunen T, Acierno JS Jr, et al: $K L B$, encoding $\beta$-Klotho, is mutated in patients with congenital hypogonadotropic hypogonadism. EMBO Mol Med 2017;9:1379-1397.

32 Zhu J, Choa RE, Guo MH, Plummer L, Buck C, Palmert MR, et al: A shared genetic basis for self-limited delayed puberty and idiopathic hypogonadotropic hypogonadism. J Clin Endocrinol Metab 2015;100:E646-E654.

33 Kelberman D, Rizzoti K, Lovell-Badge R, Robinson IC, Dattani MT: Genetic regulation of pituitary gland development in human and mouse. Endocr Rev 2009;30:790-829.

34 Parks JS, Brown MR, Hurley DL, Phelps CJ, Wajnrajch MP: Heritable disorders of pituitary development. J Clin Endocrinol Metab 1999;84:4362-4370.

35 Achermann JC, Gu WX, Kotlar TJ, Meeks JJ, Sabacan LP, Seminara SB, et al: Mutational analysis of $D A X 1$ in patients with hypogonadotropic hypogonadism or pubertal delay. J Clin Endocrinol Metab 1999;84:4497-4500.

36 Wolf NI, Vanderver A, van Spaendonk RM, Schiffmann R, Brais B, Bugiani M, et al; $4 \mathrm{H}$ Research Group: Clinical spectrum of $4 \mathrm{H}$ leukodystrophy caused by $P O L R 3 A$ and $P O L R 3 B$ mutations. Neurology 2014;83:1898-1905.

37 Margolin DH, Kousi M, Chan YM, Lim ET, Schmahmann JD, Hadjivassiliou M, et al: Ataxia, dementia, and hypogonadotropism caused by disordered ubiquitination. $\mathrm{N}$ Engl J Med 2013;368:1992-2003.

38 Topaloglu AK, Lomniczi A, Kretzschmar D, Dissen GA, Kotan LD, McArdle CA, et al: Loss-of-function mutations in PNPLA6 encoding neuropathy target esterase underlie pubertal failure and neurological deficits in Gordon Holmes syndrome. J Clin Endocrinol Metab 2014;99:E2067-E2075.

39 Tata B, Huijbregts L, Jacquier S, Csaba Z, Genin E, Meyer V, et al: Haploinsufficiency of $D m x l 2$, encoding a synaptic protein, causes infertility associated with a loss of GnRH neurons in mouse. PLoS Biol 2014;12:e1001952.

40 Aligianis IA, Johnson CA, Gissen P, Chen D, Hampshire D, Hoffmann K, et al: Mutations of the catalytic subunit of RAB3GAP cause Warburg Micro syndrome. Nat Genet 2005; 37:221-223.

41 Bem D, Yoshimura S, Nunes-Bastos R, Bond FC, Kurian MA, Rahman F, et al: Loss-offunction mutations in RAB18 cause Warburg Micro syndrome. Am J Hum Genet 2011;88: 499-507.

42 Themmen APN, Huhtaniemi IT: Mutations of gonadotropins and gonadotropin receptors: elucidating the physiology and pathophysiology of pituitary-gonadal function. Endocr Rev 2000;21:551-583.

43 Layman LC, Lee EJ, Peak DB, Namnoum AB, $\mathrm{Vu} \mathrm{KV}$, van Lingen BL, et al: Delayed puberty and hypogonadism caused by mutations in the follicle-stimulating hormone $\beta$-subunit gene. N Engl J Med 1997;337:607-611.
44 de Roux N, Genin E, Carel JC, Matsuda F, Chaussain JL, Milgrom E: Hypogonadotropic hypogonadism due to loss of function of the KiSS1-derived peptide receptor GPR54. Proc Natl Acad Sci USA 2003;100:10972-10976.

45 Seminara SB, Messager S, Chatzidaki EE, Thresher RR, Acierno JS Jr, Shagoury JK, et al: The GPR54 gene as a regulator of puberty. N Engl J Med 2003;349:1614-1627.

46 Topaloglu AK, Tello JA, Kotan LD, Ozbek MN, Yilmaz MB, Erdogan S, et al: Inactivating KISS1 mutation and hypogonadotropic hypogonadism. N Engl J Med 2012;366:629635.

47 Topaloglu AK, Reimann F, Guclu M, Yalin AS, Kotan LD, Porter KM, et al: TAC3 and TACR3 mutations in familial hypogonadotropic hypogonadism reveal a key role for Neurokinin B in the central control of reproduction. Nat Genet 2009;41:354-358.

48 de Croft S, Boehm U, Herbison AE: Neurokinin $B$ activates arcuate kisspeptin neurons through multiple tachykinin receptors in the male mouse. Endocrinology 2013;154:27502760.

49 Rance NE: Menopause and the human hypothalamus: evidence for the role of kisspeptin/ neurokinin $B$ neurons in the regulation of estrogen negative feedback. Peptides 2009;30: $111-122$.

50 Dungan HM, Clifton DK, Steiner RA: Minireview: kisspeptin neurons as central processors in the regulation of gonadotropin-releasing hormone secretion. Endocrinology 2006; 147:1154-1158.

51 Sandoval-Guzmán T, Rance NE: Central injection of senktide, an $\mathrm{NK}_{3}$ receptor agonist, or neuropeptide Y inhibits LH secretion and induces different patterns of Fos expression in the rat hypothalamus. Brain Res 2004;1026: 307-312.

52 Kung TT, Crawley Y, Jones H, Luo B, Gilchrest $\mathrm{H}$, Greenfeder S, et al: Tachykinin $\mathrm{NK}_{3}$ receptor deficiency does not inhibit pulmonary eosinophilia in allergic mice. Pharmacol Res 2004;50:611-615.

53 Tusset C, Noel SD, Trarbach EB, Silveira LF, Jorge AA, Brito VN, et al: Mutational analysis of TAC3 and TACR3 genes in patients with idiopathic central pubertal disorders. Arq Bras Endocrinol Metabol 2012;56:646-652.

54 Mitsushima D, Hei DL, Terasawa E: $\gamma$ Aminobutyric acid is an inhibitory neurotransmitter restricting the release of luteinizing hormone-releasing hormone before the onset of puberty. Proc Natl Acad Sci USA 1994;91:395-399.

55 Ojeda SR, Lomniczi A, Mastronardi C, Heger S, Roth C, Parent AS, et al: Minireview: the neuroendocrine regulation of puberty: is the time ripe for a systems biology approach? Endocrinology 2006;147:1166-1174.
56 Ducret E, Anderson GM, Herbison AE: RFamide-related peptide-3, a mammalian gonadotropin-inhibitory hormone ortholog, regulates gonadotropin-releasing hormone neuron firing in the mouse. Endocrinology 2009;150:2799-2804

57 Ojeda SR, Lomniczi A, Sandau US: Glialgonadotrophin hormone $(\mathrm{GnRH})$ neurone interactions in the median eminence and the control of GnRH secretion. J Neuroendocrinol 2008;20:732-742.

58 Ojeda SR, Dubay C, Lomniczi A, Kaidar G, Matagne V, Sandau US, Dissen GA: Gene networks and the neuroendocrine regulation of puberty. Mol Cell Endocrinol 2010;324:3-11.

59 Ojeda SR, Hill J, Hill DF, Costa ME, Tapia V, Cornea A, Ma YJ: The Oct-2 POU domain gene in the neuroendocrine brain: a transcriptional regulator of mammalian puberty. Endocrinology 1999;140:3774-3789.

60 Lee BJ, Cho GJ, Norgren RB Jr, Junier MP, Hill DF, Tapia V, et al: TTF-1, a homeodomain gene required for diencephalic morphogenesis, is postnatally expressed in the neuroendocrine brain in a developmentally regulated and cell-specific fashion. Mol Cell Neurosci 2001;17:107-126.

61 Heger S, Mastronardi C, Dissen GA, Lomniczi A, Cabrera R, Roth CL, et al: Enhanced at puberty 1 (EAP1) is a new transcriptional regulator of the female neuroendocrine reproductive axis. J Clin Invest 2007;117:21452154.

62 Messina A, Langlet F, Chachlaki K, Roa J, Rasika S, Jouy N, et al: A microRNA switch regulates the rise in hypothalamic GnRH production before puberty. Nat Neurosci 2016; 19:835-844.

63 Parent AS, Franssen D, Fudvoye J, Gérard A, Bourguignon JP: Developmental variations in environmental influences including endocrine disruptors on pubertal timing and neuroendocrine control: revision of human observations and mechanistic insight from rodents. Front Neuroendocrinol 2015;38: 12-36.

64 Ong KK, Ahmed ML, Dunger DB: Lessons from large population studies on timing and tempo of puberty (secular trends and relation to body size): the European trend. Mol Cell Endocrinol 2006;254-255:8-12.

65 Biro FM, Khoury P, Morrison JA: Influence of obesity on timing of puberty. Int J Androl 2006;29:272-277; discussion 286-290.

66 Frisch RE, McArthur JW: Menstrual cycles: fatness as a determinant of minimum weight for height necessary for their maintenance or onset. Science 1974;185:949-951.

67 Elias CF: Leptin action in pubertal development: recent advances and unanswered questions. Trends Endocrinol Metab 2012;23:915.

68 Barash IA, Cheung CC, Weigle DS, Ren H, Kabigting EB, Kuijper JL, et al: Leptin is a metabolic signal to the reproductive system. Endocrinology 1996;137:3144-3147. 
69 Gill MS, Hall CM, Tillmann V, Clayton PE: Constitutional delay in growth and puberty (CDGP) is associated with hypoleptinaemia. Clin Endocrinol (Oxf) 1999;50:721-726.

70 Banerjee I, Trueman JA, Hall CM, Price DA, Patel L, Whatmore AJ, et al: Phenotypic variation in constitutional delay of growth and puberty: relationship to specific leptin and leptin receptor gene polymorphisms. Eur J Endocrinol 2006;155:121-126.

71 Pomerants T, Tillmann V, Karelson K, Jürimäe J, Jürimäe $\mathrm{T}$ : Ghrelin response to acute aerobic exercise in boys at different stages of puberty. Horm Metab Res 2006;38: 752-757.
72 Persson I, Ahlsson F, Ewald U, Tuvemo T, Qingyuan M, von Rosen D, Proos L: Influence of perinatal factors on the onset of puberty in boys and girls: implications for interpretation of link with risk of long term diseases. Am J Epidemiol 1999;150:747-755.

73 Wehkalampi K, Hovi P, Dunkel L, StrangKarlsson S, Järvenpää AL, Eriksson JG, et al: Advanced pubertal growth spurt in subjects born preterm: the Helsinki Study of Very Low Birth Weight Adults. J Clin Endocrinol Metab 2011;96:525-533.

74 Dunger DB, Ahmed ML, Ong KK: Early and late weight gain and the timing of puberty. Mol Cell Endocrinol 2006;254-255:140-145.

75 Sun Y, Bak B, Schoenmakers N, van Trotsenburg AS, Oostdijk W, Voshol P, et al: Loss-offunction mutations in IGSF1 cause an Xlinked syndrome of central hypothyroidism and testicular enlargement. Nat Genet 2012; 44:1375-1381.
76 Joustra SD, Wehkalampi K, Oostdijk W, Biermasz NR, Howard S, Silander TL, et al: IGSF1 variants in boys with familial delayed puberty. Eur J Pediatr 2015;174:687-692.

77 Howard SR, Guasti L, Ruiz-Babot G, Mancini A, David A, Storr HL, et al: IGSF10 mutations dysregulate gonadotropin-releasing hormone neuronal migration resulting in delayed puberty. EMBO Mol Med 2016;8:626-642.

78 Boehm U, Bouloux PM, Dattani MT, de Roux N, Dodé C, Dunkel L, et al: Expert consensus document: European Consensus Statement on congenital hypogonadotropic hypogonadism - pathogenesis, diagnosis and treatment. Nat Rev Endocrinol 2015;11:547-564. 